\title{
PENGARUH KOMPENSASI FINANSIAL DAN NON FINANSIAL TERHADAP KINERJA KARYAWAN PT. SAHABAT PRIMA SUKSES
}

\author{
Moch. Rizal ${ }^{1}$, Fensi Handayani \\ ${ }^{1,2}$ STIE Muhammadiyah Jakarta, rizalbisnis@yahoo.com; handayanifensi77@ gmail.com
}

\begin{abstract}
ABSTRAK
Pemberian kompensasi finansial dan non finansial sangat penting bagi karyawan dan perusahaan, karena menjadi salah satu motivasi karyawan untuk meningkatkan kinerja kerjanya. Jika kinerja kerja karyawan meningkat maka akan berpengaruh juga terhadap pencapaian tujuan perusahaan. Penelitian ini bertujuan untuk menjelaskan pengaruh kompensasi finansial dan kompensasi non finansial terhadap kinerja karyawan PT. Sahabat Prima Sukses secara parsial dan simultan. Sampel pada penelitian ini berjumlah 40 orang dengan teknik pengambilan menggunakan sampel jenuh. metode pengumpulan data dengan kuesioner. Analisis data menggunakan analisis deskriptif dan analisis regresi linier berganda dengan pengujian hipotesis menggunakan uji parsial, uji simultan dan koefesien determinasi. Hasil penelitian menunjukkan tidak semua hipotesis diterima, dimana kompensasi finansial berpengaruh negatif dan tidak signifikan terhadap kinerja karyawan sedangkan kompensasi non finansial berpengaruh positif dan signifikan terhadap kinerja karyawan. Artinya semakin baik kompensasi non finansial yang diberikan perusahaan maka kinerja karyawan akan semakin meningkat. Oleh karena itu perusahaan harus lebih meningkatkan kompensasi non finansial terutama dalam membuat kebijakan organisasi yang berpengaruh terhadap kenyamanan karyawan.
\end{abstract}

Kata kunci : Kompensasi Finansial, Kompensasi Non Finansial dan Kinerja Karyawan

\section{ABSTRACT}

Financial and non-financial compensation is very important for employees and companies, because it is one of the motivations of employees to improve their work performance. If the employee's work performance improves it will also affect the achievement of the company's goals. This research aims to explain the effect of financial compensation and non-financial compensation on the performance of PT employees. Sahabat Prima Sukses partially and simultaneously. The sample in this study numbered 40 people with saturated sampling techniques. Method of data collection with questionnaires. Data analysis uses descriptive analysis and multiple linear regression analysis with hypothetical testing using partial testing, simultaneous testing and coefficient determination. The results showed that not all hypotheses is accepted, where financial compensation had a negative and insignificant effect on employee performance, while non-financial compensation had a positive and significant effect on employee performance. This means that the better the non-financial compensation provided by the company, the employee's performance will increase. Therefore the company must further increase non-financial compensation, especially in making organizational policies that affect employee comfort.

Keywords: Financial Compensation, Non Financial Compensation and Employee Performance

Naskah diterima : 08-10-2020 Naskah dipublikasikan: 31-03-2021 


\section{PENDAHULUAN}

Perusahaan perlu memperhatikan kesejahteraan sumber daya manusia dan sadar bahwa sumber daya manusia lebih dari sekedar aset. Perusahaan harus bisa bersikap profesional dan adil dalam pemberian imbalan kepada karyawan sebagai timbal balik atas jasa yang telah diberikan kepada perusahaan. Hal tersebut mendorong karyawan agar lebih termotivasi dalam menjalankan dan mengerjakan tugas-tugasnya demi terwujudnya tujuan perusahaan. Hubungan kerja yang saling menguntungkan tersebut berdampak positif terutama bagi perusahaan, karena dapat meningkatkan kinerja karyawan dan tujuan perusahaan dapat tercapai. Karyawan memberikan jasanya dengan kinerja yang baik untuk kemajuan perusahaan dan perusahaan memberikan imbalan atau kompensasi kepada karyawan atas jasanya (Anwar Mangkunegara, 2001: 1).

Menurut S.P. Hasibuan (2019) Kompensasi adalah semua pendapatan yang berbentuk uang, barang langsung atau tidak langsung yang diterima karyawan sebagai imbalan atas jasa yang diberikan kepada perusahaan. Panggabean menggolongkan kompensasi ke dalam dua kelompok, yaitu kompensasi finansial dan kompensasi non finansial.

Salah satu contoh perusahaan yang dapat dinilai kinerja karyawannya baik dari segi kompensasi finansial maupun non finansial yaitu PT. Sahabat Prima Sukses. Data yang diperoleh dari Human Resources Development (HRD) PT Sahabat Prima Sukses diketahui persentase jumlah karywan yang mengundurkan diri dari tahun 2018 sampai bulan Juni 2020 sebagai berikut:

Tabel 1.Data Turn over karyawan PT. Sahabat Prima Sukses tahun 2018- Juni 2020

\begin{tabular}{|c|c|c|c|c|c|}
\hline Tahun & $\begin{array}{c}\text { Jumlah Karyawan } \\
\text { Awal Tahun }\end{array}$ & Masuk & Keluar & $\begin{array}{c}\text { Jumlah Karyawan } \\
\text { Akhir Tahun }\end{array}$ & $\begin{array}{c}\text { Persentase } \\
\text { Turnover }\end{array}$ \\
\hline 2018 & 46 & 8 & 9 & 45 & $2,20 \%$ \\
\hline 2019 & 45 & 26 & 21 & 50 & $10,53 \%$ \\
\hline 2020 & 50 & 5 & 15 & 40 & $22,22 \%$ \\
\hline
\end{tabular}

Sumber : Data HRD diolah, 2020

Menurut Ridho (2012), keinginan untuk pindah dapat dijadikan gejala awal terjadinya turn over dalam sebuah perusahaan. Turn over karyawan menimbulkan banyak dampak negatif yang tentunya memberikan kerugian bagi perusahaan. Salah satunya mengakibatkan turunnya produktivitas beberapa orang karyawan sehingga dapat menghambat optimalisasi produktivitas perusahaan secara umum. Menurut Siagian (20018) kinerja karyawan dipengaruhi beberapa faktor yaitu kompensasi, lingkungan kerja, budaya organisasi, kepemimpnan dan motivasi kerja, disiplin kerja, kepuasan kerja, komunikasi dan faktor-faktor lainnya.

Penelitian yang terkait dengan penelitian ini didukung adanya perbedaan hasil dari penelitian terdahulu, dimana pengaruh kompensasi terhadap kinerja karyawan menunjukkan hasil yang tidak konsisten. Berdasarkan penelitian yang dilakukan oleh Zairina Afrida, Bambang Swasto Sunuharyo dan Endang Siti Astuti (2014) menunjukkan bahwa kompensasi finansial, kompensasi non finansial, dan motivasi kerja memiliki pengaruh signifikan terhadap kinerja karyawan. Dengan pengujian hipotesis bahwa variabel motivasi kerja dalam penelitian ini bertindak sebagai mediator yang memediasi variable bebas kompensasi finansial dan non finansial terhadap variabel terikat kinerja 
karyawan. Sedangkan Slamet Riyadi (2011) dalam penelitiannya menunjukkan bahwa kompensasi finansial tidak mempengaruhi motivasi kerja maupun kinerja karyawan. Sedangkan gaya kepemimpinan secara signifikan mempengaruhi motivasi kerja maupun kinerja karyawan, dan motivasi kerja secara signifikan mempengaruhi kinerja karyawan.

Penelitian lain dilakukan Larbiel Hadi (2014) menunjukkan bahwa kompensasi finansial dan kompensasi non finansial secara simultan berpengaruh positif dan signifikan terhadap kinerja karyawan. Sedangkan hasil penelitian yang dilakukan oleh Sastia Amalia (2019) kompensasi finansial tidak berpengaruh signifikan terhadap kinerja karyawan dan kompensasi non finansial berpengaruh secara signifikan terhadap kinerja karyawan.

Berdasarkan uraian di atasterdapat adanya perbedaan hasil dari penelitian terdahulu, dimana pengaruh kompensasi terhadap kinerja karyawan menunjukkan hasil yang tidak konsisten. Oleh karena itu perbedaan hasil penelitian tersebut perlu untuk diperjelas lagi temuan bukti empiris tentang sejauh mana pengaruh kompensasi finansial dan non finansial terhadap kinerja karyawan.Adapun tujuan dari penelitian ini adalah untuk mengetahui pengaruh kompensasi finansial dan non finansial terhadap kinerja karyawan PT. Sahabat Prima Sukses.

\section{KAJIAN LITERATUR Kompensasi}

Menurut T Hani Handoko (2016) Kompensasi adalah segala sesuatu yang diterima para karyawan sebagai balas jasa untuk kerja mereka. Sedangkan Menurut Mondiani (2012) Kompensasi merupakan apa yang diterima oleh para karyawan sebagai ganti kontribusi mereka kepada organisasi. Samsudin Sadili (2010) menjelaskan bahwa organisasi atau instansi dalam rangka memberikan balas jasa atau kompensasi memiliki tujuan sebagai berikut :

a. Pemenuhan Kebutuhan Ekonomi

b. Meningkatkan Produktivitas Kerja

c. Memajukan Organisasi Atau Perusahaan

d. Menciptakan Keseimbangan Dan Keadilan

\section{Kompensasi Finansial}

Menurut Bangun (2012:255), Kompensasi finansial adalah bentuk kompensasi yang dibayarkan kepada karyawan dalam bentuk uang atas jasa yang mereka sumbangkan pada perusahaan. Kompensasi finansial terdiri atas dua bagian yaitu kompensasi langsung dan kompensasi tidak langsung.

\section{Kompensasi Non Finansial}

Kompensasi finansial tidak langsung merupakan tunjangan, yang meliputi semua imbalan finansial yang tidak mencakup dalam kompensasi finansial langsung. Indarjanti (20120), menjelaskan bahwa "Kompensasi tidak langsung disebut juga dengan tunjangan, yaitu imbalan tidak langsung yang diberikan kepada karyawan sebagai anggota organisasi seperti asuransi, jaminan kesehatan, pembayaran waktu tidak bekerja, dan pensiun". Contoh kompensasi finansial tidak langsung seperti program asuransi tenaga kerja atau BPJS Ketenagakerjaan, pembayaran biaya sakit atau BPJS Kesehatan, cuti dan lain-lain. 


\section{Kinerja Karyawan}

Kinerja berasal dari kata job performance atau actual performance yang berarti prestasi kerja atau prestasi sesungguhnya yang dicapai oleh seseorang. Kinerja adalah hasil kerja yang dicapai seseorang secara kuantitas dan kualitas dalam melaksanakan fungsinya sesuai dengan tanggung jawab yang diberikan kepadanya (Mangkunagara 2015).

Menurut Irawan (2014) kinerja adalah hasil atau tingkat keberhasilan seseorang secara keseluruhan selama periode tertentu dalam melaksanakan tugas dibandingkan dengan berbagai kemungkinan, seperti standar hasil kerja, target atau sasaran atau kriteria yang telah ditentukan terlebih dahulu telah disepakati bersama.

\section{PENGEMBANGAN HIPOTESIS}

Kompensasi Finansial dapat diberikan secara langsung terdiri atas bayaran yang diperoleh seseorang dalam bentuk gaji, upah, bonus, atau komisi Mondy (2016). Kompensasi finansial dapat memberikan pengaruh yang paling penting dan signifikan terhadap kinerja karyawan. Sistem kompensasi akan memberikan dua tujuan paling penting yaitu mendorong karyawan untuk merasa memiliki dalam organisasi dan mendorong untuk berprestasi yang lebih tinggi lagi. Penelitian yang dilakukan Edrick Leonardo dan Fransisca Andreani (2015) menunjukkan bahwa kompensasi finansial memiliki pengaruh lebih dominan terhadap kinerja karyawan dibandingkan kompensasi non finansial.

H1: Kompensasi finansial berpengaruh positif terhadap kinerja karyawan PT. SahabatPrima Sukses

Kompensasi non finansial merupakan imbalan dalam bentuk kepuasan seseorang yang diperoleh dari pekerjaan itu sendiri, atau dari lingkungan baik secara fisik ataupun psikologis dimana orang tersebut bekerja. Ciri dari kompensasi non finansial ini meliputi kepuasan yang didapat dari pelaksana tugas-tugas yang bermakna yang berhubungan dengan pekerjaan (Mondy 2016). Penelitian yang dilakukan Ekshu Hamdan dan Roy Setiawan (2014) menunjukkan bahwa kompensasi non finansial berpengaruh positif dan signifikan terhadap kinerja karyawan.

H2: Kompensasi non finansial berpengaruh positif terhadapkinerja karyawan PT.Sahabat Prima Sukses

Kompensasi merupakan hal yang penting dalam manajemen sumber daya manusia. Pemberian kompensasi yang baik dan tepat akan meningkatkan motivasi para karyawan. Karyawan akan termotivasi dengan bekerja sebaik mungkin, untuk menambah jumlah pendapatan mereka dalam bentuk kompensasi. Penelitian yang dilakukan Eta Setyawan, Suseno Djamhurdan Hamid Ika Ruhana (2014) menunjukkan bahwa Terdapat pengaruh yang signifikan antara kompensasi finansial dan non finansial terhadap kinerja karyawan baik secara simultan maupun secara parsial.

H3: Kompensasi finansial dan kompensasi non finansial secara simultan berpengaruh positif terhadap kinerja karyawan PT. Sahabat Prima Sukses 


\section{Kerangka Pemikiran}

Berdasarkan uraian di atas, maka dibuat suatu kerangka teoritis seperti gambar berikut ini.

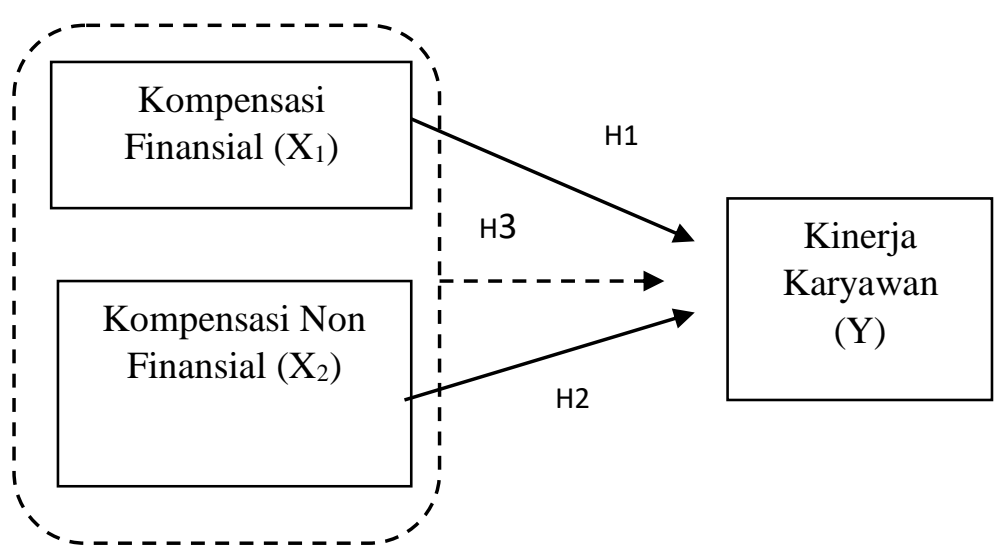

Gambar 1. Kerangka Pemikiran Penelitian

\section{METODE PENELITIAN}

Penelitian ini mengggunakan pendekatan kuantitatif dengan variabel independen yaitu kompensasi finansial dan non finansial sedangkan variabel dependen yaitu kinerja karyawan. Unit analisis yang diteliti adalah karyawan PT. Sahabat Prima Sukses dengan populasi sebanyak 40 orang. Karena jumlah populasi kurang dari 100, maka sampel yang diambil adalah seluruh karyawan PT. Sahabat Prima Sukses. Metode sampling yang digunakan adalah Probability Sampling dimana seluruh karyawan PT. Sahabat Prima Sukses mempunyai peluang yang sama untuk dipilih menjadi anggota sampel. Sedangkan untuk jenis sampling, penelitian ini menggunakan Simple Random Sampling karena pengambilan sampel anggota populasi dilakukan secara acak tanpa memperhatikan strata yang ada dalam populasi itu.

Teknik pengumpulan data pada penelitian ini menggunakan kuesioner, dengan sumber data dari data primer dan sekunder. Data primer diperoleh dari kuesioner, sedangkan data sekunder berupa data pendukung yang diperoleh dari perusahaan. Adapun teknik analis data yang digunakan adalah uji instrumen, uji asumsi klasik dan uji hipotesis. 


\section{HASIL DAN PEMBAHASAN Uji Validitas}

Tabel 2. Hasil Uji Validitas Variabel Kompensasi Finansial, Non Finansial dan Kinerja Karyawan

\begin{tabular}{|c|c|c|c|c|c|}
\hline No. Butir Pernyataan & $\begin{array}{c}\mathbf{r} \text { hitung } \\
\mathbf{X}_{\mathbf{1}}\end{array}$ & $\begin{array}{c}\mathbf{r} \text { hitung } \\
\mathbf{X}_{\mathbf{2}}\end{array}$ & $\begin{array}{c}\mathbf{r} \text { hitung } \\
\mathbf{Y}\end{array}$ & $\mathbf{r}$ tabel & Keterangan \\
\hline Pernyataan 1 & 0,394 & 0,653 & 0,499 & 0,312 & Valid \\
\hline Pernyataan 2 & 0,556 & 0,767 & 0,672 & 0,312 & Valid \\
\hline Pernyataan 3 & 0,829 & 0,524 & 0,736 & 0,312 & Valid \\
\hline Pernyataan 4 & 0,801 & 0,592 & 0,727 & 0,312 & Valid \\
\hline Pernyataan 5 & 0,711 & 0,667 & 0,596 & 0,312 & Valid \\
\hline Pernyataan 6 & 0,447 & 0,409 & 0,797 & 0,312 & Valid \\
\hline Pernyataan 7 & 0,547 & 0,545 & 0,547 & 0,312 & Valid \\
\hline Pernyataan 8 & - & 0,421 & 0,723 & 0,312 & Valid \\
\hline Pernyataan 9 & - & 0,637 & - & 0,312 & Valid \\
\hline
\end{tabular}

Sumber : Data primer diolah, 2020

Berdasarkan tabel di atas dilihat bahwa koefisien korelasi dari setiap butir pernyataan untuk variabel kompensasi finansial, non finansial dan kinerja karyawan karyawan dinyatakan valid, karena $r_{\text {hitung }}>$ $r_{\text {tabel }}(0,312)$.

\section{Uji Reliabilitas}

Tabel 3. Hasil Uji Reliabilitas

\begin{tabular}{|l|c|c|c|}
\hline \multicolumn{1}{|c|}{ Variabel } & Standard Alpha & Cronbach Alpha & Keterangan \\
\hline Kompensasi Finansial $\left(\mathrm{X}_{1}\right)$ & 0,60 & 0,733 & Reliabel \\
\hline $\begin{array}{l}\text { Kompensasi Non Finansial } \\
\left(\mathrm{X}_{2}\right)\end{array}$ & 0,60 & 0,722 & Reliabel \\
\hline Kinerja Karyawan $(\mathrm{Y})$ & 0,60 & 0,820 & Reliabel \\
\hline
\end{tabular}

Sumber : Data primer diolah, 2020

Berdasarkan tabel di atas nilai Cronbach's Alpha untuk variabel kompensasi finansial, kompensasi non finansial, dan kinerja karyawan >0,6. Hasil tersebut menunjukkan bahwa item pertanyaan untuk variabel kompensasi finansial, kompensasi non finansial, dan kinerja karyawan reliabel. 


\section{JURNAL EKOBIS: EKONOMI, BISNIS \& MANAJEMEN}

\section{Vol 11 Nomor 1 (2021)}

\section{Uji Normalitas}

Tabel 4. Hasil Uji Normalitas

One-Sample Kolmogorov-Smirnov Test

\begin{tabular}{|ll|r|}
\hline & & \multicolumn{2}{|c|}{ Unstandardized Residual } \\
\hline $\mathrm{N}$ & & 40 \\
Normal Parameters & $\mathrm{a}, \mathrm{b}$ & Mean \\
& Std. Deviation &, 0000000 \\
Most Extreme & Absolute & 2,87258017 \\
Differences & Positive &, 105 \\
& Negative &, 105 \\
Test Statistic & &,- 105 \\
Asymp. Sig. (2-tailed) & &, 105 \\
\hline
\end{tabular}

a. Test distribution is Normal.

b. Calculated from data.

Sumber : Data primer diolah, 2020

Berdasarkan tabel di atas nilaiAsymp. Sig (2-tailed) > 0,05 maka dapat disimpulkan bahwa residual menyebar dengan normal.

\section{Uji Multikolinearitas}

Tabel 5. Hasil Uji Multikolinearitas Coefficients $^{\mathrm{a}}$

\begin{tabular}{|l|r|r|}
\hline \multirow{2}{*}{ Model } & \multicolumn{2}{|c|}{ Collinearity Statistics } \\
\cline { 2 - 3 } 1 (Constant) & \multicolumn{1}{|c|}{ Volerance } \\
Kompensasi Finansial &, 675 & 1,482 \\
Kompensasi Non Finansial &, 675 & 1,482 \\
\hline
\end{tabular}

a. Dependent Variabel: Kinerja Karyawan

Sumber : Data primer diolah, 2020

Berdasarkan tabel di atas dapat dilihat pada kolom tolerance dan VIF. Hasil tolerance kedua variabel independen Kompensasi Finansial $\left(X_{1}\right)$ 0,675 dan Kompensasi Non Finansial $\left(X_{2}\right)$ 0,675, nilai tersebut menunjukkan $>0,10$. Nilai VIF kedua variabel independen Kompensasi Finansial $\left(\mathrm{X}_{1}\right)$ 1,482 dan Kompensasi Non Finansial $\left(\mathrm{X}_{2}\right)$ 1,482 yang menunjukkan bahwa nilai tersebut < 10,00 , oleh karena itu dapat disimpulkan bahwa tidak ada multilolinearitas di antara kedua variabel independen dalam model regresi. 


\section{Analisis Regresi Linear Berganda}

Tabel 6. Hail Analisis Regresi Linear Berganda Coefficients $^{\mathbf{a}}$

\begin{tabular}{|l|r|r|}
\hline \multirow{2}{*}{ Model } & \multicolumn{2}{|c|}{ Unstandardized Coefficients } \\
\cline { 2 - 3 } & \multicolumn{1}{|c|}{ B } & \multicolumn{1}{c|}{ Std. Error } \\
\hline 1 (Constant) & 15,545 & 5,441 \\
Kompensasi Finansial &, 046 &, 149 \\
Kompensasi Non Finansial &, 445 &, 186 \\
\hline
\end{tabular}

a. Dependent Variabel: Kinerja Karyawan

Sumber : Data primer diolah, 2020

Maka didapat persamaannya seperti di bawah ini :

$\mathrm{Y}=15,545+0,046 \mathrm{X}_{1}+0,445 \mathrm{X}_{2}+\mathrm{e}$

Persamaan regresi di atas dijelaskan sebagai berikut: Pertama, konstanta besarnya 15,545 bernilai positif, dengan koefisien Kompensasi Finansial $\left(\mathrm{X}_{1}\right)$ dan Kompensasi Non Finansial $\left(\mathrm{X}_{2}\right)$ bernilai nol (0), maka diperoleh Kinerja Karyawan sebesar 15,545. Hal ini berarti apabila Kompensasi Finansial dan Kompensasi Non Finansial dianggap tidak ada atau sama dengan nol maka skor Kinerja Karyawan sebesar 15,545. Kedua, koefisienregresi Kompensasi Finansial ( $\left.\mathrm{X}_{1}\right)$ sebesar 0,046 bernilai positif, maka setiap penambahan satu satuan skor Kompensasi Finansial $\left(\mathrm{X}_{1}\right)$ akan meningkatkan skor Kinerja Karyawan sebesar 0,046 dengan asumsi variabel independen lainnya tetap. Ketiga, koefisien Kompensasi Non Finansial $\left(\mathrm{X}_{2}\right)$ sebesar 0,445 bernilai positif, maka setiap penambahan satu satuan skor Kompensasi Non Finansial $\left(\mathrm{X}_{2}\right)$ akan meningkatkan skor Kinerja Karyawan sebesar 0,445 dengan asumsi variabel independen lainnya tetap.

\section{Uji Parsial (Uji t)}

Tabel 7. Hasil Uji Parsial

Coefficients $^{\mathrm{a}}$

\begin{tabular}{|l|r|r|}
\hline & & \\
\hline 1 (Constant) & \multicolumn{1}{|c|}{$\mathrm{T}$} & \multicolumn{1}{c|}{ Sig. } \\
\hline Kompensasi Finansial & 2,857 &, 007 \\
Kompensasi Non Finansial &, 310 &, 758 \\
\end{tabular}

a. Dependent Variabel: Kinerja Karyawan

Sumber : Data primer diolah, 2020

Berdasarkan tabel diatas pada variabel kompensasi finansial diperoleh $t_{\text {hitung }}$ sebesar 0,310 dengan nilai signifikan 0,758. Hal ini menunjukkan bahwa nilai thitung lebih keci ldari nilai $\mathrm{t}_{\text {tabel }}$ sebesar2,026. Perbandingan $t_{\text {hitung }}$ denga $t_{\text {tabel }}$ didapat hasil $0,310<2,026$ atau $t_{\text {hitung }}<\mathrm{t}_{\text {tabel }}$. Sedangkan perbandingan nilai signifikan yang didapat $0,758>0,050$. Hal ini menunjukkan tingkat signifikan yang lebih besar dari tingkat kesalahan. Artinya kompensasi finansial tidak berpengaruh secara parsial terhadap kinerja karyawan. Sedangkan pada variabel kompensasi non 
finansial diperoleh $t_{\text {hitung }}$ sebesar 2,395 dengan nilai signifikan 0,022. Hal ini menunjukkan bahwa nilai $t_{\text {hitung }}$ lebih besar dari nilai $t_{\text {tabel }}$ sebesar 2,026. Perbandingan $t_{\text {hitung }}$ denga $t_{\text {tabel }}$ didapat hasil $2,395>2,026$ atau $t_{\text {hitung }}>\mathrm{t}_{\text {tabel }}$. Sedangkan perbandingan nilai signifikan yang didapat $0,022<$ 0,05 . Hal ini menunjukkan tingkat signifikan yang lebih kecil dari tingkat kesalahan. Artinya kompensasi non finansial berpengaruh secara parsial terhadap kinerja karyawan.

\section{Uji Simultan (Uji f)}

Tabel 8. Hasil Uji Simultan (Uji F)

TANOVA ${ }^{\mathrm{a}}$

\begin{tabular}{|l|r|r|r|r|c|}
\hline Model & \multicolumn{1}{|c|}{$\begin{array}{c}\text { Sum of } \\
\text { Squares }\end{array}$} & Df & $\begin{array}{c}\text { Mean } \\
\text { Square }\end{array}$ & F & Sig. \\
\hline Regression & 86,083 & 2 & 43,042 & 4,949 &, $012^{\mathrm{b}}$ \\
Residual & 321,817 & 37 & 8,698 & & \\
Total & 407,900 & 39 & & & \\
\hline
\end{tabular}

a. Dependent Variabel: Kinerja Karyawan

b. Predictors: (Constant), Kompensasi Non Finansial, Kompensasi

Finansial

Sumber : Data primer diolah, 2020

Berdasarkan uji $\mathrm{F}$ yang telah dilakukan, maka didapatkan bahwa pengaruh antara variabel independent (kompensasi finansial dan kompensasi non finansial) terhadap variabel dependent (kinerja karyawan) adalah kuat dan berpengaruh secara simultan. Hal ini dapat dilihat pada nilai $\mathrm{F}$ hitung > F tabel atau 4,949 > 3,24 dengan taraf signifikan sebesar 0,012 < 0,05 yang berarti kompensasi finansial dan kompensasi non finansial secara bersama-sama (simultan) berpengaruh terhadap kinerja karyawan.

\section{Uji Koefisien Determinasi (R2)}

Tabel 9. Hasil Uji Koefesien Determinasi Model Summary ${ }^{\mathrm{b}}$

\begin{tabular}{|l|r|r|r|r|}
\hline Model & \multicolumn{1}{|c|}{$\mathrm{R}$} & R Square & $\begin{array}{c}\text { Adjusted R } \\
\text { Square }\end{array}$ & $\begin{array}{c}\text { Std. Error of } \\
\text { the Estimate }\end{array}$ \\
\hline 1 &, $459^{\mathrm{a}}$ &, 211 &, 168 & 2,949 \\
\hline
\end{tabular}

a. Predictors: (Constant), Kompensasi Non Finansial, Kompensasi Finansial b. Dependent Variable: Kinerja Karyawan Sumber : Data primer diolah, 2020

Berdasarkan tabel di atas menunjukkan bahwa variabel independen (Kompensasi Finansial dan Kompensasi Non Finansial) berpengaruh sebesar 0,211 atau 21,1\% terhadap Kinerja Karyawan, sedangkan sisanya 78,9\% dijelaskan oleh variabel lain di luar penelitian ini. 


\section{Pembahasan}

Pengaruh Kompensasi Finansial terhadap Kinerja Karyawan di PT. Sahabat Prima Sukses

Hasil penelitian menunjukkan bahwa kompensasi finansial tidak berpengaruh secara parsial terhadap kinerja karyawan di PT. Sahabat Prima Sukses. Hal ini dibuktikan dengan Uji Parsial (Uji t). Perbandingan $t_{\text {hitung }}$ dengan $t_{\text {tabel }}$ di dapat hasil $0,310<2,026$ atau $t_{\text {hitung }}<t_{\text {tabel }}$. Sedangkan perbandingan nilai signifikan yang didapat 0,758 > 0,050 menunjukkan tingkat signifikan yang lebih besar dari tingkat kesalahan, dengan demikian maka Ho diterima dan Ha ditolak. Berdasarkan hasil tersebut dapat disimpulkan bahwa kompensasi finansial secara parsial berpengaruh negatif dan tidak signifikan terhadap kinerja karyawan PT. Sahabat Prima Sukses artinya variabel kompensasi finansial tidak berpengaruh nyata terhadap variabel kinerja karyawan.

Hasil penelitian ini menunjukkan adanya keselarasan dengan penelitian sebelumnya yang dilakukan oleh Slamet Riyadi (2011) bahwa hasil uji t untuk variabel kompensasi finansial berpengaruh negatif dan tidak signifikan terhadap kinerja karyawan. Dengan demikian perlu ada insentif atau motivasi lainnya karena terbukti secara empiris bahwa kompensasi finansial tidak mempengaruhi kinerj akaryawan..

\section{Pengaruh Kompensasi Non Finansial terhadap Kinerja Karyawan di PT. Sahabat Prima Sukses}

Hasil penelitian menunjukkan bahwa Kompensasi Non Finansial berpengaruh secara parsial terhadap kinerja karyawan di PT. Sahabat Prima Sukses. Hal ini dibuktikan dengan Uji Parsial (Uji t). Perbandingan $t_{\text {hitung }}$ dengan $t_{\text {table }}$ didapat hasil $2,395>2,026$ atau $t_{\text {hitung }}>\mathrm{t}_{\text {tabel. }}$. Sedangkan perbandingan nilai signifikan yang didapat $0,022<0,05$. Hal ini menunjukkan tingkat signifikan yang lebih kecil dari tingkat kesalahan, dengan demikian maka Ho ditolak dan Ha diterima. Berdasarkan hasil tersebut dapat disimpulkan bahwa kompensasi non finansial secara parsial berpengaruh positif dan signifikan terhadap kinerja karyawan PT. Sahabat Prima Sukses.

Hasil penelitian ini menunjukkan adanya keselarasan dengan penelitian sebelumnya yang dilakukan oleh Larbiel Hadi (2014) bahwa hasil uji t untuk variabel kompensasi non finansial berpengaruh positif dan signifikan terhadap kinerja karyawan.

Pengaruh Kompensasi Finansial dan Kompensasi Non Finansial secara bersama-sama terhadap Kinerja Karyawan di PT. Sahabat Prima Sukses

Hasil penelitian ini menunjukkan bahwa terdapat pengaruh positif antara kompensasi finansial dan kompensasi non finansial secara bersama-sama terhadap kinerja karyawan. Hal ini dibuktikan dengan Uji Simultan (Uji F) Perbandingan F hitung > F tabel atau 4,949> 3,24 dengan taraf signifikan sebesar 0,012<0,05 yang berarti kompensasi finansial dan kompensasi non finansial secara bersama-sama (simultan) berpengaruh terhadap kinerja karyawan PT. Sahabat Prima Sukses.

Penelitian ini mendukung penelitian sebelumnya Sastia Amalia (2019) yang menunjukkan hasil bahwa kompensasi finansial tidak berpengaruh signifikan terhadap kinerja karyawan dan kompensasi non finansial berpengaruh secara signifikan terhadap kinerja karyawan. Perusahaan perlu melakukan pendekata lain untuk melakukan perbaikan kinerja karyawan karena terbukti secara empiris bahwa pengaruh kompensasi baik finansial maupun non finansial terbukti tidak mempengaruhi kinerja karyawan. 


\section{PENUTUP \\ Simpulan}

Berdasarkan hasil penelitian dan pembahasan di atas, kesimpulan yang dapat dirangkum adalah sebagai berikut : Pertama, Kompensasi finansial berpengaruh negatif dan tidak signifikan terhadap kinerja karyawan dimana hasil ini menolak hipotesis pertama. Kedua, Kompensasi non finansial berpengaruh positif dan signifikan terhadap kinerja karyawan dimana hasil ini mendukung hipotesis kedua yang diajukan. Terakhir, Kompensasi finansial dan kompensasi non finansial berpengaruh secara simultan terhadap kinerja karyawan dimana hasil ini mendukung hipotesis yang diajukan.

\section{Saran}

Penelitian mengenai pengaruh kompensasi finansial dan non finansial terhadap kinerja karyawan PT. Sahabat Prima Sukses, diharapkan dapat memberikan saran dan masukan sebagai pertimbangan perusahaan dalam meningkatkan kinerja karyawan. Bagi PT. Sahabat Prima Sukses. Mengingat kompensasi non finansial adalah variabel yang mempengaruhi kinerja karyawan, maka hendaknya perusahaan lebih memperhatikan mengenai pemberian kompensasi non finansial terhadap karyawan. Penelitian selanjutnya dapatmenambahkan variabel-variabel lain yang memiliki hubungan cukup erat untuk berpengaruh terhadap kinerja karyawan, seperti gaya kepemimpinan, budaya organisasi, motivasi kerja dan lingkungan kerja.

\section{REFERENSI}

Danny Hendra Irawan, Djamhur Hamid, dan Muhammad Faisal Riza. (2014). Pengaruh Kompensasi Finansial Dan Kompensasi Non Finansial Terhadap Kinerja (Studi Pada Agen Ajb Bumiputera 1912 Kantor Cabang Blitar). Jurnal Administrasi Bisnis (JAB). 13(1), 1-9.

Edrick Leonardo dan Fransisca Andreani (2015). Pengaruh Pemberian Kompensasi Terhadap Kinerja Karyawan Pada PT. Kopanitia. Journal Manajemen Bisnis (AGORA). 3(2), 28-31.

Ekshu Hamdandan Roy Setiawan (2014). Pengaruh Kompensasi Finansial Dan Non Finansial Terhadap Kinerja Karyawan PT. Samudera Buana Persada. Journal Manajemen Bisnis (AGORA). 2(1), 1-5.

Eta Setyawan Suseno, Djamhur Hamid, dan Ika Ruhana. (2014). Pengaruh Kompensasi Finansial Dan Non Finansial Terhadap Kinerja Karyawan (Studi pada Bank Rakyat Indonesia Cabang Jember). Jurnal Administrasi Bisnis (JAB).8(2), 1-6.

Ganyang, MT. (2018). Manajemen Sumber Daya Manusia Konsep dan Realita. In Media. Bogor.

Handoko, T. H. (2016). Manajemen personalia dan sumberdaya manusia. BPFE.

Hasibuan, Malayu S.P. (2019) Manajemen Sumber Daya Manusia. Edisi Revisi. PT. Bumi Aksara. Jakarta.

Indarjanti, P., \& Bodroastuti, T. (2012). Pengaruh Kemampuan, Usaha Dan Dukungan Organisasi Terhadap Kinerja. Jurnal Kajian Akuntansi dan Bisnis, 1(1), 102597.

Irawan, D. H. (2014). Pengaruh kompensasi finansial dan kompensasi non finansial terhadap kinerja (studi pada agen AJB Bumiputera 1912 Kantor Cabang Blitar). Jurnal Administrasi Bisnis, 13(2).

Larbiel Hadi (2014). Pengaruh Kompensasi Finansial Dan Non Finansial Terhadap Kinerja Karyawan BUMN (Studi Kasus PT. Bank Rakyat Indonesia (Persero) Tbk. Cabang Teluk Kuantan). Jurnal Al-Iqtishad. 10(2), 50-72. 
Mangkunegara, A. P., \& Waris, A. (2015). Effect of training, competence and discipline on employee performance in company (case study in PT. Asuransi Bangun Askrida). ProcediaSocial and Behavioral Sciences, 211, 1240-1251.

Mardiansyah. (2011) Pengaruh Kompensasi Finansial Langsung terhadap Kinerja Karyawan dengan Motivasi Ekstrinsik sebagai variable intrervening pada Karyawan bagian penjualan PT. Mitra Pinasthika Mustika Surabaya. Skripsi. Universitas Airlangga Surabaya.

Mita D. Marliani, Tommy Parengkuan, dan Victor P.K. Lengkong. (2016). Pengaruh Kompensasi Finansial Langsung, Kompensasi Finansial Tidak Langsung Dan Kompensasi Non Finansial Terhadap Kinerja Karyawan Pada Pt. Telkom Manado. Jurnal Ekonomi Manajemen Bisnis dan Akuntansi (EMBA). 4(4), 1108-1117.

Mondy, R., \& Martocchio, J. J. (2016). Human resource management. Pearson.

Mondiani, T. (2012). Pengaruh kepemimpinan transformasional dan kompensasi terhadap kinerja karyawan PT. PLN (PERSERO) UPJ Semarang. Jurnal Administrasi Bisnis, 1(1), 46-54.

MT, Bintoro. Dan Daryanto (2017). Manajemen Penilaian Kinerja Karyawan. Gava Media. DIY. Priyono. (2010) Manajemen Sumber Daya Manusia. Zifatama. Sidoarjo.

Ridlo, I. A. (2012). Turnover karyawan "Kajian literatur". Surabaya: PH Movement Publication.

Roihatul Musyafi', Hamidah Nayati Utami, danYuniadi Mayowan. (2016). Pengaruh Kompensasi Finansial Dan Non Finansial Terhadap Kinerja Karyawan (Studi Pada Karyawan PT. PLN (Persero) Area Pelayanan Dan Jaringan (Apj) Malang). Jurnal Administrasi Bisnis (JAB). 39(2), 149-157.

Samsudin, S. (2010). Manajemen Sumber Daya Manusia. Bandung. Pustaka Setia.

Sedarmayanti (2009). Sumber Daya Manusia dan Produktivitas Kerja. CV. Mandar Maju. Bandung.

Siagian, M. (2018). Peranan Disiplin Kerja Dan Kompensasi Dalam Mendeterminasi Kinerja Karyawan Dengan Motivasi Kerja Sebagai Variabel Intervening Pada Pt Cahaya Pulau Pura Di Kota Batam. JIM UPB (Jurnal Ilmiah Manajemen Universitas Putera Batam), 6(2), 22-33

Sihombing, Sarinah. Gultom, R. Simon. Dan Sidjabat, Sonya. (2015). Manajemen Sumber Daya Manusia. Edisi Revisi. In Media. Bogor.

Slamet Riyadi (2011). Pengaruh Kompensasi Finansial, Gaya Kepemimpinan, dan Motivasi Kerja Terhadap Kinerja Karyawan pada Perusahaan Manufaktur di Jawa Timur.

JurnalManajemendanKewirausahaan. 13(1), 40-45.

Supomo, R dan Nurhayati, Eti. (2018) Manajemen Sumber Daya Manusia. Yrama Widia. Bandung.

Zairina Afrida, Bambang Swasto Sunuharyo, dan Endang Siti Astuti. (2014). Pengaruh Kompensasi Finansial Dan Non Finansial Terhadap Motivasi Kerja Dan Kinerja Karyawan (Studi Pada Karyawan Departemen Produksi PT. Ekamas Fortuna Malang). Jurnal Administrasi Bisnis (JAB).12(1), 1-9. 